\title{
Carbocyclic Isoadenosine Analogues of Neplanocin A
}

\author{
Katherine L. Seley, Sylvester L. Mosley, Fanxing Zeng
}

\section{Supporting Information}

General. Melting points were recorded on a Meltemp II melting point apparatus and are uncorrected. Combustion analyses were performed by Atlantic Microlabs, Inc., Atlanta, GA. UV spectral data was obtained on a Varian Cary 100 Bio UV-Vis spectrometer. ${ }^{1} \mathrm{H}$ and ${ }^{13} \mathrm{C}$ spectra were recorded on a Bruker 300 spectrometer (operated at 300 and $75 \mathrm{MHz}$, respectively) all referenced to internal tetramethylsilane (TMS) at $0.0 \mathrm{ppm}$. The spin multiplicities are indicated by the symbols s (singlet), d (doublet), dd (doublet of doublets), $\mathrm{t}$ (triplet), and $\mathrm{m}$ (multiplet). Reactions were monitored by thin-layer chromatography (TLC) using $0.25 \mathrm{~mm}$ Whatman Diamond silica gel $60-\mathrm{F}_{254}$ precoated plates with visualization by irradiation with a Mineralight UVGL-25 lamp. Column chromatography was performed on Whatman silica, 200-400 mesh, $60 \AA$ and elution with the indicated solvent system. Yields refer to chromatographically and spectroscopically $\left({ }^{1} \mathrm{H}\right.$ and $\left.{ }^{13} \mathrm{C} \mathrm{NMR}\right)$ homogeneous materials.

(+)-2,3-(Isopropylidenedioxy)-4-cyclopenten-1-ol (4): To a stirred solution of cyclopentenone (-)-31 (2.31 $\mathrm{g}, 15.00 \mathrm{mmol})$ and $\mathrm{CeCl}_{3} \cdot 7 \mathrm{H}_{2} \mathrm{O}(5.59 \mathrm{~g}, 15.00 \mathrm{mmol})$ in $\mathrm{MeOH}(70 \mathrm{~mL})$ at $0{ }^{\circ} \mathrm{C}$ was added in small portions $\mathrm{NaBH}_{4}(1.13 \mathrm{~g}, 30.00 \mathrm{mmol})$. $^{2}$ After stirring at $\mathrm{rt}$ for $1 \mathrm{~h}$ the mixture was neutralized with conc. $\mathrm{HCl}$, reduced to $2 / 3$ volume, extracted with brine and ether, and the organic layers combined, dried $\left(\mathrm{MgSO}_{4}\right)$, and concentrated to give 4 as a yellow syrup $(2.32 \mathrm{~g}, 99 \%)$ which was used directly in the next step. Spectral data was in agreement with literature values. ${ }^{3}$

1-Bromo-2,3-(isopropylidenedioxy)cyclopent-4-ene (5): To a stirred solution of 4-nitrobenzoic acid (3.00 g, $17.95 \mathrm{mmol}), \mathrm{PPh}_{3}(4.71 \mathrm{~g}, 17.95 \mathrm{mmol})$ in dry THF (100 mL) was added DIAD (3.63 g, 17.95 $\mathrm{mmol})$, and the mixture stirred under argon at $\mathrm{rt}$ for $15 \mathrm{~min}$. A solution of 4 (1.4 g, $8.97 \mathrm{mmol})$ in dry THF $(50 \mathrm{~mL})$ was then added, and the mixture stirred at $55{ }^{\circ} \mathrm{C}$ for $3 \mathrm{~d}$. The solvent was removed under vacuum and the resulting syrup purified by column chromatography eluting with hexane:EtOAc (9:1) to give 2,3(isopropylidenedioxy)-1-[( $p$-nitrobenzoyl)oxy $]$ cyclopent-4-ene a white solid $(2.40 \mathrm{~g}, 88 \%)$ which was used directly in the next step without further purificantion. ${ }^{4}$

To a stirred solution of 2,3-(isopropylidenedioxy)-1-[( $p$-nitrobenzoyl)oxy]cyclopent-4-ene (1.52 g, 5.00 $\mathrm{mmol})$ in $\mathrm{MeOH}(100 \mathrm{~mL})$ in $\mathrm{H}_{2} \mathrm{O}$, was added $\mathrm{KOH}(0.56 \mathrm{~g}, 10.00 \mathrm{mmol})$ and the reaction mixture was stirred at $\mathrm{rt}$ for $1 \mathrm{~h}$. The $\mathrm{MeOH}$ was removed by evaporation, and the resulting aqueous mixture extracted with $\mathrm{CH}_{2} \mathrm{Cl}_{2}$, dried $\left(\mathrm{MgSO}_{4}\right)$, and concentrated to give (-)-2,3-(isopropylidenedioxy)-4-cyclopenten-1-ol as a yellow syrup $(0.73 \mathrm{~g}, 94 \%)$, which was used directly in the next step. Spectral data was in agreement with literature values. ${ }^{3}$

To a stirred solution of (-)-2,3-(isopropylidenedioxy)-4-cyclopenten-1-ol (0.73 g, $4.70 \mathrm{mmol})$ and $\mathrm{PPh}_{3}$ $(2.46 \mathrm{~g}, 9.4 \mathrm{mmol})$ in DMF $(15 \mathrm{~mL})$ was added at $0{ }^{\circ} \mathrm{C} \mathrm{NBS}(1.67 \mathrm{~g}, 9.4 \mathrm{mmol})$. After stirring at $\mathrm{rt}$ for $3 \mathrm{~h}$ the mixture was added to $\mathrm{H}_{2} \mathrm{O}$, extracted with $\mathrm{CH}_{2} \mathrm{Cl}_{2}$, dried $\left(\mathrm{MgSO}_{4}\right)$, concentrated, and purified by column chromatography eluting with hexane:EtOAc $(5: 1)$ to give $\mathbf{5}$ as an unstable yellow syrup $(0.61 \mathrm{~g}$, 60\%). ${ }^{1} \mathrm{H}$ NMR $\left(\mathrm{CDCl}_{3}\right) \square 1.36(\mathrm{~s}, 3 \mathrm{H}), 1.39$ (s, 3H), 4.84 (s, 1H), $4.96(\mathrm{~d}, 1 \mathrm{H}), 5.33$ (m, 1H), $5.98(\mathrm{~m}, 2 \mathrm{H})$; ${ }^{13} \mathrm{C} \mathrm{NMR}\left(\mathrm{CDCl}_{3}\right) \square 26.7,27.9,54.9,84.4,86.3,112.4,134.3,135.3$.

(-)-2,3-(Isopropylidenedioxy)-1-[(methanesulfonyl)oxy]-cyclopent-4-ene (6): To a stirred solution of 4 (1.63 $\mathrm{g}, 10.46 \mathrm{mmol})$ and pyridine $(25 \mathrm{~mL})$ in $\mathrm{CH}_{2} \mathrm{Cl}_{2}(50 \mathrm{~mL})$ at $0{ }^{\circ} \mathrm{C}$ was added $\mathrm{MsCl}(3.59 \mathrm{~g}, 31.38$ mmol). After stirring at $\mathrm{rt}$ for $3 \mathrm{~h}$, cold $\mathrm{H}_{2} \mathrm{O}(50 \mathrm{~mL})$ was added to the reaction mixture and then washed sequentially with $1 \mathrm{~N} \mathrm{HCl}(2 \times 50 \mathrm{~mL})$ and brine $(2 \times 50 \mathrm{~mL})$, dried $\left(\mathrm{MgSO}_{4}\right)$, concentrated, and purified by column chromatography eluting with hexane:EtOAc (5:1) to afford 6 as a yellow syrup $(2.01 \mathrm{~g}, 82.1 \%)$. Spectral data was in agreement with literature values. ${ }^{4}$ 
(-)-2,3-(Isopropylidenedioxy)-1-[(p-tolylsulfonyl)oxy]-cyclopent-4-ene (7): Using the identical method as was used for 6, but substituting TsCl (2.31 g, $14.82 \mathrm{mmol}$ ), afforded 7 as a yellow syrup (3.86 g, 84\%). Spectral data was in agreement with literature values. ${ }^{4}$

(-)-3-(2',3'-Dihydroxycyclopent-4'-enyl)adenine (1): A solution of adenine $(0.78 \mathrm{~g}, 5.80 \mathrm{mmol})$ and 5 $(1.40 \mathrm{~g}, 6.30 \mathrm{mmol})$ in $N, N$-dimethylacetamide $(10 \mathrm{~mL})$ was heated at $110{ }^{\circ} \mathrm{C}$ for $2 \mathrm{~d}$. The reaction mixture was cooled to rt and the solvent was removed under vacuum. The resulting brown solid was dissolved in a small amount of hot $\mathrm{H}_{2} \mathrm{O}$, neutralized with $\mathrm{NH}_{4} \mathrm{OH}$, and placed in the refrigerator. After $5 \mathrm{~h}$ a tan precipitate formed, which was isolated and purified by column chromatography eluting with EtOAc:MeOH (9:1) to afford 3-(2', 3'-isopropylidenedioxy-4',5'-cyclopentene)adenine as a white solid (1.12 g, 64\%), mp $>260{ }^{\circ} \mathrm{C} .{ }^{1} \mathrm{H}$ NMR $\left(\mathrm{CD}_{3} \mathrm{OD}\right) \square 1.33(\mathrm{~s}, 3 \mathrm{H}), 1.47(\mathrm{~s}, 3 \mathrm{H}), 4.80(\mathrm{~d}, 1 \mathrm{H}), 5.56(\mathrm{dd}, 1 \mathrm{H}), 5.85(\mathrm{~s}, 1 \mathrm{H}), 6.03(\mathrm{dd}$, $1 \mathrm{H}), 6.40(\mathrm{dd}, 1 \mathrm{H}), 7.93(\mathrm{~s}, 1 \mathrm{H}), 8.13(\mathrm{~s}, 1 \mathrm{H}) ;{ }^{13} \mathrm{C}$ NMR $\left(\mathrm{CD}_{3} \mathrm{OD}\right) \square 25.4,27.1,70.8,72.7,83.6,85.5$, 113.3, 121.4, 130.0, 140.3, 142.2, 150.3, 153.6, 157.8. Anal. Calcd. for $\mathrm{C}_{13} \mathrm{H}_{15} \mathrm{~N}_{5} \mathrm{O}_{2}: \mathrm{C}, 56.21 ; \mathrm{H}, 5.63 ; \mathrm{N}$, 25.20. Found: C, 56.31; H, 5.57; N, 24.84.

A solution of 3-(2',3'-isopropylidenedioxy-4',5'-cyclopentene)adenine (100 mg, $0.36 \mathrm{mmol})$ in TFA/ $\mathrm{H}_{2} \mathrm{O}$ (2:1) was stirred at $\mathrm{rt}$ for $2 \mathrm{~h}$. The solution was concentrated and co-evaporated with $\mathrm{MeOH}$ to remove all traces of TFA, and the resulting syrup crystallized using ethyl acetate:MeOH (9:1) to afford $\mathbf{1}$ as a fine white powder (84 mg, 99\%); mp 181-183 ${ }^{\circ} \mathrm{C}$. UV $\left(\mathrm{H}_{2} \mathrm{O}\right), 274 \mathrm{~nm} .{ }^{1} \mathrm{H}$ NMR $\left(\mathrm{CD}_{3} \mathrm{OD}\right) \square 4.50(\mathrm{t}, 1 \mathrm{H}), 4.69$ $(\mathrm{m}, 1 \mathrm{H}), 5.62(\mathrm{~m}, 1 \mathrm{H}), 6.15(\mathrm{dd}, 1 \mathrm{H}), 6.30(\mathrm{~m}, 1 \mathrm{H}), 7.90(\mathrm{~s}, 1 \mathrm{H}), 8.20(\mathrm{~s}, 1 \mathrm{H}) ;{ }^{13} \mathrm{C}$ NMR $\left(\mathrm{CD}_{3} \mathrm{OD}\right) \square 72.8$, 74.5, 77.6, 121.3, 132.5, 138.4, 144.0, 150.6, 153.1, 156.8. HRMS [m/z +1] Calcd. 234.090. Found 234.099.

(+)-3-(2',3'-Dihydroxycyclopent-4'-enyl)adenine (2): Synthesized in an analogous fashion as was used for 1, however starting with (+)-3 gave $\mathbf{2}$ as a fine white powder $(0.89 \mathrm{~g}, 43 \%$ in six steps from (+)-3)); $\mathrm{mp}$ 182-183 ${ }^{\circ} \mathrm{C}$. UV $\left(\mathrm{H}_{2} \mathrm{O}\right) 274 \mathrm{~nm} .{ }^{1} \mathrm{H}$ NMR $\left(\mathrm{CD}_{3} \mathrm{OD}\right) \square 4.57(\mathrm{t}, 1 \mathrm{H}), 4.72(\mathrm{~m}, 1 \mathrm{H}), 5.77(\mathrm{~m}, 1 \mathrm{H}), 6.13(\mathrm{dd}$, $1 \mathrm{H}), 6.33(\mathrm{~m}, 1 \mathrm{H}), 8.44(\mathrm{~s}, 1 \mathrm{H}), 8.54(\mathrm{~s}, 1 \mathrm{H}) ;{ }^{13} \mathrm{C} \mathrm{NMR}\left(\mathrm{CD}_{3} \mathrm{OD}\right) \mathrm{7} 71.8,73.3,76.9,111.1,130.8,137.6$, 144.8, 146.3, 148.4, 154.1; HRMS [m/z+1] Calcd. 234.090, Found 234.099

\section{References}

(1) Siddiqi, S. M.; Schneller, S. W.; Ikeda, S.; Snoeck, R.; Andrei, G.; Balzarini, J.; De Clercq, E. Nucleosides Nucleotides 1993, 12, 185-198.

(2) Luche, J.-L.; Rodriguez-Hahn, L.; Crabbe, P. J. Chem. Soc., Chem. Commun. 1978, 601-602.

(3) Seley, K. L.; Schneller, S. W.; Rattendi, D.; Lane, S.; Bacchi, C. J. J. Med. Chem. 1997, 40, 625-629.

(4) Mosley, S. L. Masters, Georgia Institute of Technology, 2001. 


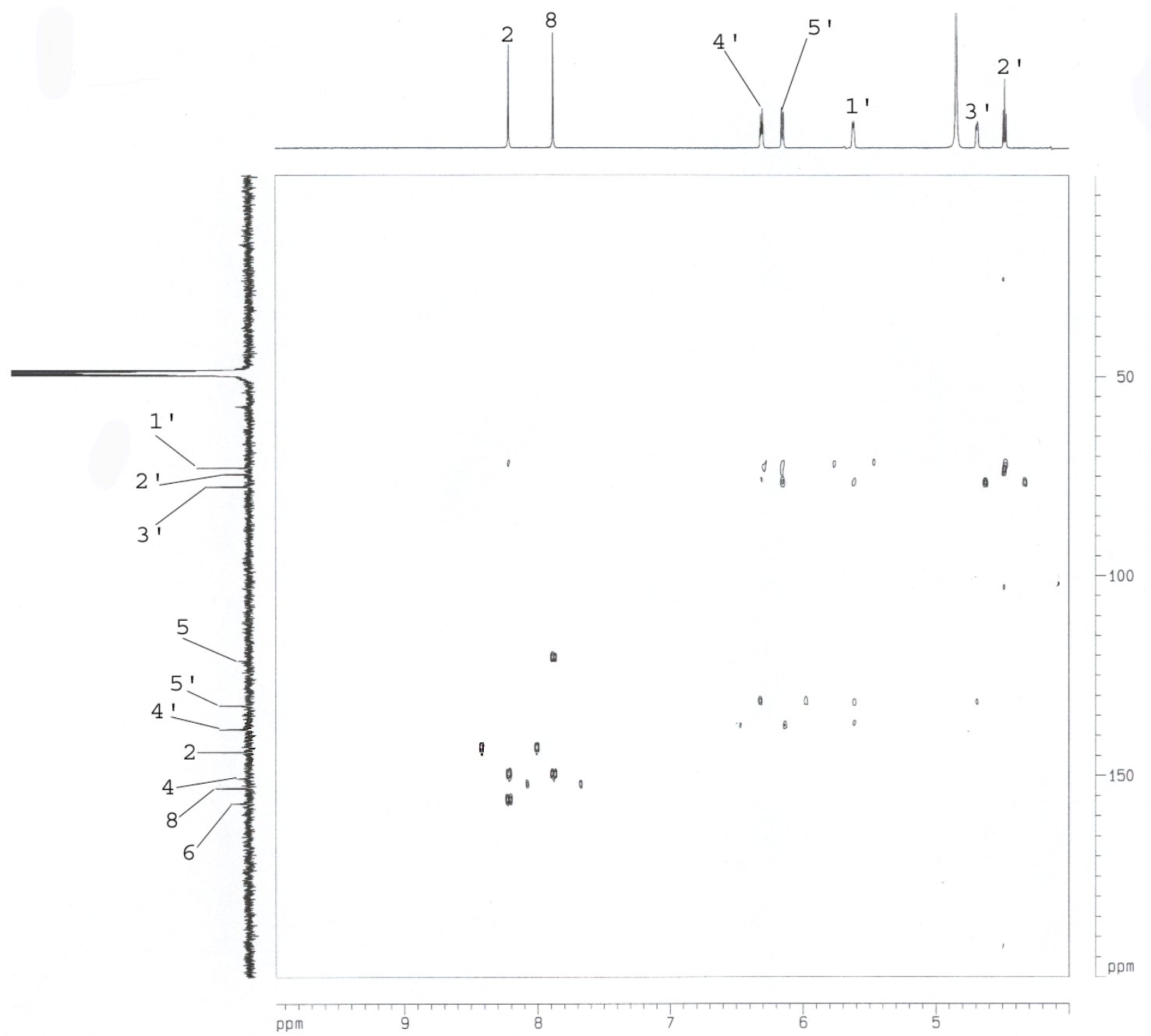




$$
f
$$

